\title{
ПЕРСПЕКТИВИ РОЗВИТКУ ЕКОЛОГІЧНОГО ТУРИЗМУ В УКРАЇНІ
}

\author{
Посохов Іван Сергійович \\ кандидат історичних наук, доцент \\ Харківський національний університет імені В. Н. Каразіна \\ м. Свободи, 6, м. Харків, Україна 61022 \\ e-mail: ivanposokhov@karazin.ua \\ ORCID: https://orcid.org/0000-0001-8638-5148 \\ Сагайдачна Анастасія Віталіївна \\ магістрант \\ Харківський національний університет імені В. Н. Каразіна \\ м. Свободи, 6, м. Харків, Україна 61022 \\ e-mail:anastasiya.vs@ukr.net \\ ORCID: https://orcid.org/0000-0001-5386-6025
}

\begin{abstract}
На сучасному етапі розвитку туризму в світі, одним із пріоритетних напрямків сталого розвитку територій став екологічний туризм. Розвиток екологічного туризму в Україні на початковому етапі, але завдяки існуючій природно-рекреаційним ресурсам країни, цей вид туризму має усі шанси стати одним з основних видів подорожей та створити усі умови покращення соціально-економічного становища населення. Предметом дослідження в статті $€$ перспективи розвитку екологічного туризму в Україні на основі існуючої ресурсної бази. Мета полягає вобґрунтуванні стану розвитку екологічного туризму в Україні та його перспектив. Завдання: розбір поняття «екологічний туризм», аналіз сучасного стану розвитку екологічного туризму в Україні, розгляд нормативно-правового регулювання та визначення перспектив розвитку екологічного туризму.

В статті використовуються загальнонаукові методи дослідження: аналіз - для дослідження окремих складових екологічного туризму; синтез - для об'єднання окремих фактів; статистичний метод - для обробки статистичної інформації та для якісної оцінки даних; метод індукції та дедукції - допомагає зробити висновки на основі існуючих фактів; системний підхід - для цілісного дослідження перспектив екологічного туризму відносно зовнішніх факторів впливу. Отримано такі результати: на основі проведеного аналізу було досліджено теоретичні аспекти поняття «екологічний туризм», виявлені необхідні ресурси на сучасному етапі розвитку екологічного туризму в країні та визначені головні перспективи. Висновки: обґрунтовані перспективи розвитку екологічного туризму відображають позитивний ефект від екотуристичної діяльності в Україні, що свідчить про важливість його організації та розвиток на внутрішньому туристичному ринку країни.

Ключові слова: екологічний туризм, еко-готелі, навколишнє середовище, природно-заповідні території,сталий розвиток туризму, туристична діяльність.
\end{abstract}

Постановка проблеми. На сьогоднішній день, глобальні екологічні проблеми привертають увагу всього людства. Екологічна криза стала поштовхом до усвідомлення проблем екології та подальших дій в покращенні ситуації. В свою чергу, туризм дає можливість цілісного бачення природи, людини і культури. Важливою умовою здійснення туристичної діяльності $є$ наявність природнорекреаційних ресурсів як екологічного середовища існування людини, що також формує екологічну культуру населення.

Туристична діяльність має важливе значення, як Аля економіки країн, так і для їх соціального розвитку. Туризм сприяє підвищенню культурного рівня людини, Аопомагає засвоїти нові знання, цінності та загальні норми поведінки. Завдяки туризму людина самовдосконалюється, реалізує свої рекреаційні, пізнавальні та духовні потреби. Тож, відбувається інтерналізація особистості. В цих умовах і виникає почуття відповідальності людини до навколишнього середовища та бажання покращити екологію.

Поява екологічного туризму -це певна відповідь людства на глобальні екологічні проблеми та зростаюче споживання природних ресурсів. На сьогоднішній день, екологічний туризм стрімко розвивається i набуває популярності у багатьох країнах, що допомагає гармонізувати відносини між природою, людьми та економікою. Розвиток екологічного туризму в Україні на сучасному етапі є перспективним в багатьох регіонах країни, завдяки їх унікальним природним ресурсам та прагненню населення до відпочинку на природі. Зважаючи на це, запровадження розвитку екологічного туризму в Україні є актуальним.

Розвиток екологічного туризму може значно покращити економічно-соціальне становище країни. Це оптимальний та ефективний механізм стримування негативних процесів. За допомогою екологічного туризму можна взаємозбагатити культури різних народів, зміцнити взаємну довіру, налагодити міжнародні відносини та обмін туристами, покращити умови розвитку внутрішнього туризму і надати країні гарний імідж та конкурентоспроможність.

Аналіз останніх досліджень та публікацій. Теоретичною та методологічною основою Аля дослідження екологічного туризму став доробок вітчизняних та зарубіжних вчених. Серед них необхідно виокремити праці вчених, таких як: О. О. Бейдик, В. І. Вишневський, О. Ю. Амитрук, 


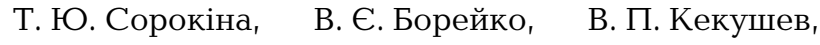
В. В. Храбовченко, Е. Ю. Колбовський. Статистичною базою дослідження також слугували звіти Аержавної служби статистики України, матеріали звітів Міністерства екології та природних ресурсів України.

Мета статті. Обґрунтування перспектив розвитку екологічного туризму в Україні на основі теоретичних та аналітичних досліджень.

Виклад основного матеріалу.Екологічний туризм - достатньо новий напрям туристичної діяльності в світі. Саме в 2002 році, в рамках міжнародного року екологічного туризму, на Всесвітньому саміті була затверджена Квебекська декларація з екологічного туризму, що стала одним з основних документів у світі щодо екотуристичної діяльності, що започаткувало його стрімкий розвиток [3, с. 180].

На сьогодні існує безліч різних визначень поняття «екологічний туризм», але вперше його запропонував мексиканський економіст та еколог Гектор Цебаллос-Ааскурейн, як його ще називають у світі «архітектор екологічного туризму», ще в 1980 році. Він виявив, що екологічний туризм - це поєднання подорожі довідносно не змінених природних зон, 3 обов'язковим об'єктом дослідження, разом 3 повагою та турботою до дикої природи, живих організмів та культури, спільно із сприянням їх захисту[4, с. 17].

Український вчений О.О. Бейдик визначив, що екологічний туризм - це рекреаційна діяльність, яка має найменший вплив на природне середовище, передбачає гармонійне єднання природи, людини, засобів рекреації та рекреаційної інфраструктури. В той час, О. Ю. Амитрук вважає, що екологічний туризм можна визначити як інтегруючий напрямок рекреаційної діяльності, спрямований на гармонізацію відносин між туристами, туроператорами, природним середовищем та місцевими громадами, що реалізується через екологізацію всіх видів туристичної діяльності, охорону природи, екологічну освіту та виховання [3, с. 7].

Через розмитість поняття екотуризму, його часто плутають з іншими напрямками туризму: сільський зелений туризм, агротуризм, біотуризм, природний туризм, пригодницький та деякі інші. Вони суміжні, але мають віддалене відношення до екологічного туризму, тому що підтримують інші цілі та не відповідають головним його принципам.

Основні принципи екотуризму направленні на покращення добробуту населення та зменшення негативного впливу туристичних потоків на навколишнє середовище.Головною ідеєю екологічного туризму є піклування та збереження природного навколишнього середовища, що використовуєтьсядля туристичних цілей та реалізується в його завданнях та функціях[4, с. 27].

Розвиток екологічного туризму в Україні знаходиться на початковому етапі. Аля його становлення необхідною умовою $є$ природнорекреаційні ресурси, що будуть привертати увагу туристів. Завдяки гарному географічному положенню, Україна багата на різноманітні природні та рекреаційні ресурси, які можна використовувати в розвитку екологічного туризму.

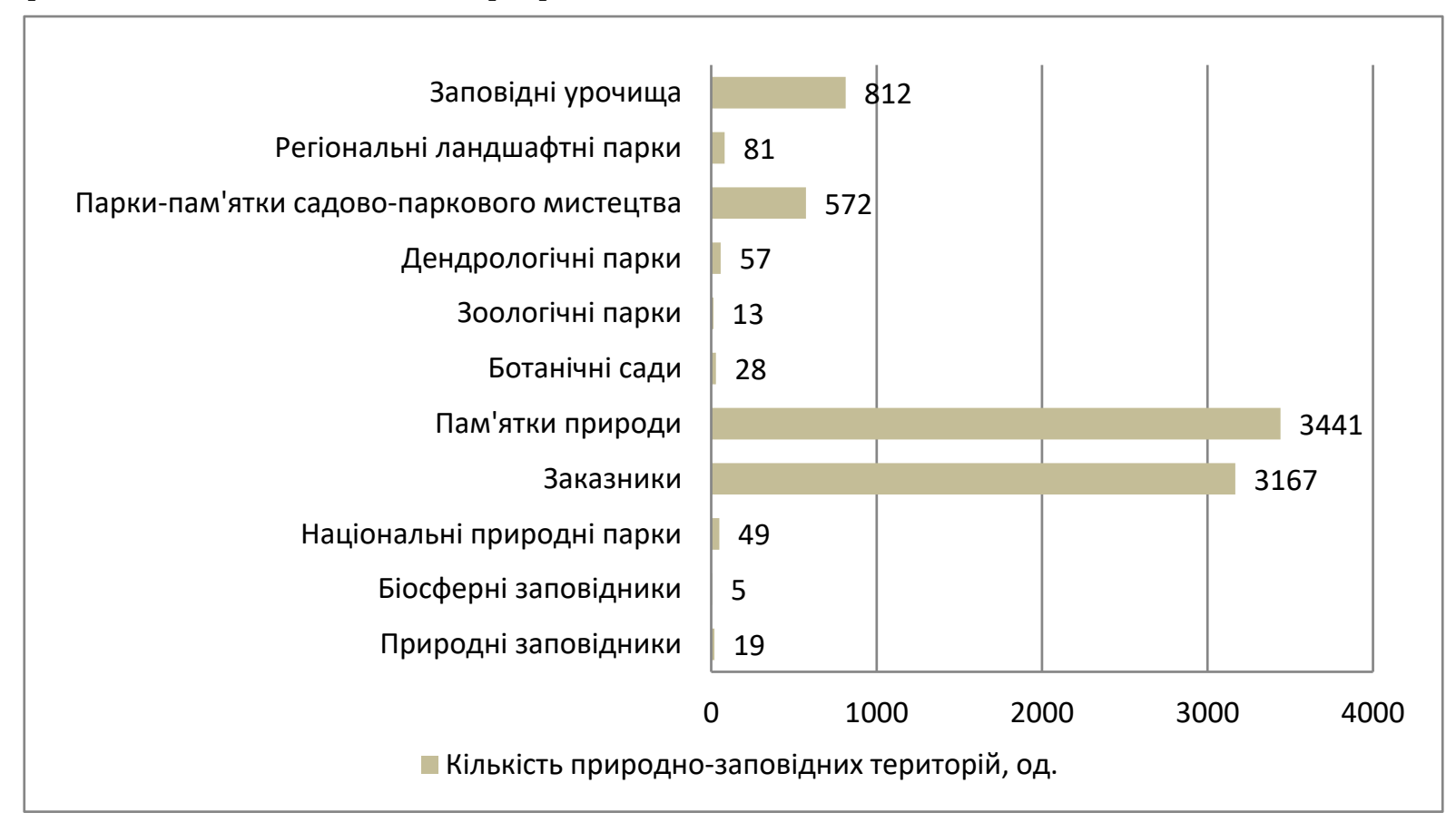

Рис. 1. Кількість прирояно-заповіgних територій та об'єктів ПЗФ Украӥни, станом на 01.01.2017 р., og. Розроблено авторами за матеріалами: [12] 
Територія країни поділяється на 3 природні зони: Полісся, лісостеп та степ, де наявні унікальні природні території, які привабливі Аля екотуристів. Особливими рекреаційними регіонами країни є Карпатські гори та Чорне i Азовське моря. В Україні унікальне біорізноманіття, що становить більше 70 тис. видів, з яких - понад 27 тис. видів налічує фолора, та понад 45 тис. має фауна [13].Територія лісів становить 10,6 млн. га, тобто 17,6 \% території країни [8].

Аивлячись на те, що в світі є дві моделі розвитку екологічного туризму - австралійська, де організація туризму відбувається в межах дикої природи та західноєвропейська - подорожі в межах особливо охоронюваних природних територій, то в Україні пріоритетною моделлю розвитку екотуризму на внутрішньому ринку туристичних послуг є остання [4, с. 18].

В Україні в свою чергу, безліч різноманітних об'єктів природно-заповідного фонду, які впливають на розвиток та перспективи екологічного туризму. Станом на 01.01.2018p. природно-заповідний фонд України налічує 8296 території та об'єктів, загальна площа якого 4,318 млн га в межах території України, де фрактична площа становить 3,985 млн га, інша частина0,403млн га в межах акваторії Чорного моря [10]. Кожен рік кількість об'єктів природнозаповідного фонду змінюється. Так, за 2017 р. було створено 54 об'єкти природно-заповідного фонду, збільшено територію 7 об'єктів (Закарпатська, Київська, Аонецька та Ауганська області), зменшено території 3 інших і скасовано статус 4 об'єктів. Наприклад, важливою подією Аля України стало створення п'ятого біосферного заповідника 26.04.2016 p. - Чорнобильського радіаційно-екологічного біосферного заповідника, за площею 226964,7 га в межах Київської області[10].

Ресурсна база об'єктів ПЗФ достатньо велика, як на місцевому рівні, так і на національному, що надає усі можливості для розвитку екологічного туризму в усіх регіонах України. Лідерами за кількістю природно-заповідних територій $\epsilon$ Чернігівська область, що налічує 665 одиниць, Тернопільська обл. - 639 од., Черкаська обл. 540 од., Хмельницька обл. - 522 од. та Закарпатська обл. - 468 од. [12].

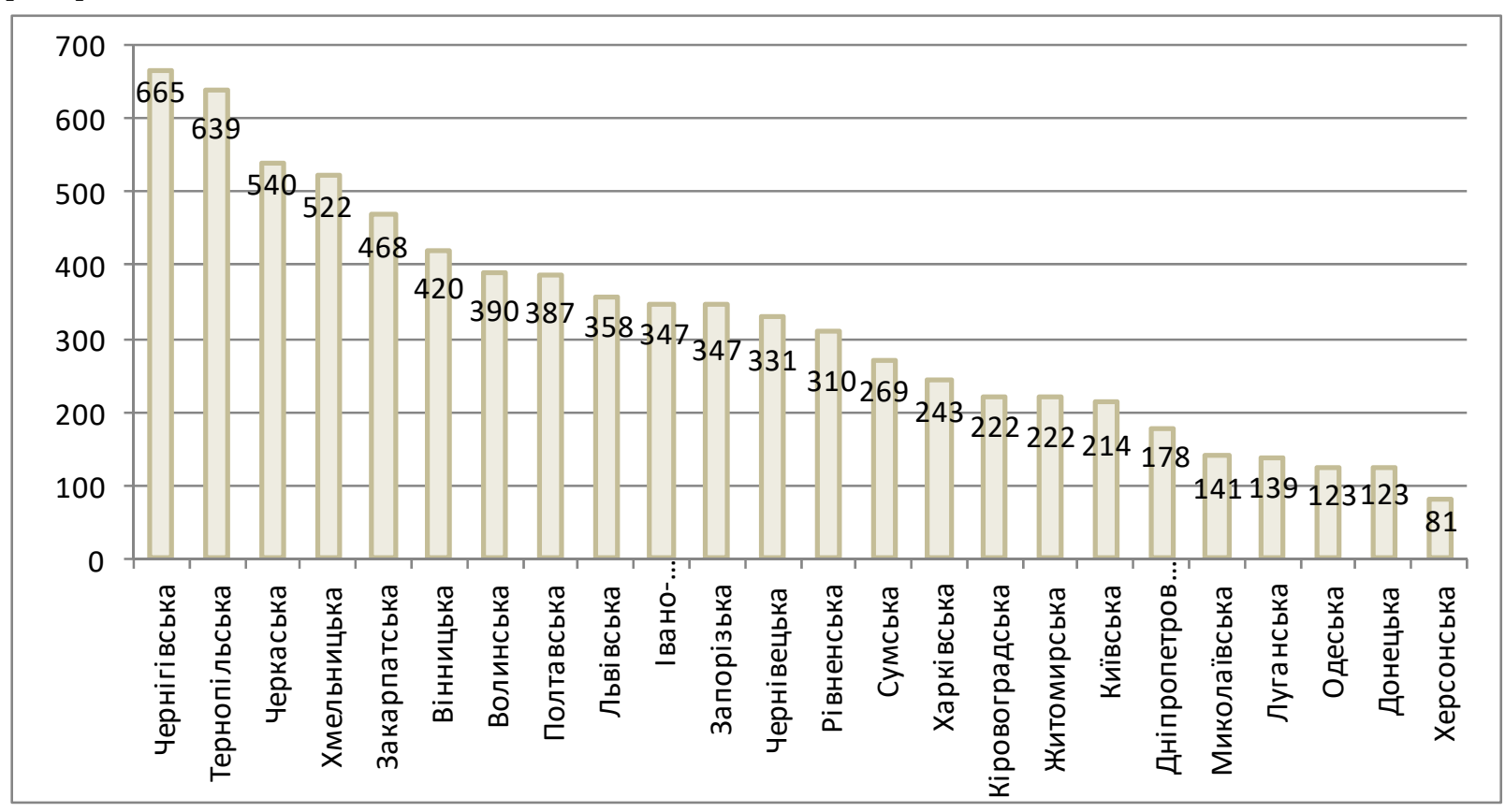

Рис. 2. Кількість прирояно-заповіgних територій в кожній області Украӥни, станом на 01.01.2018 р., оg. Розроблено авторами за матеріалами: [12]

В Україні є різноманітна ресурсна база підприємств розміщення у кожному регіоні. Станом на 2017 р. колективних засобів розміщення - 4115 од., 3 яких: 2474 од. - готелі та аналогічні засоби розміщення, та спеціалізовані засоби розміщення - 1641 од. [9]. ОАнак, Аля розміщення екотуристів, зазвичай, використовують еко-готелі. На сучасному етапі, Україна є учасником міжнародної сертифрікаційної програми «GreenKey» та на 2018 рік займає 21 місце, поряд із Швейцарією, Іспанією, Тунісом та Аомініканською Республікою, маючи 8 сертифікованих еко-готелів.

Загальна кількість готелів у світі, які пройшли екологічну сертифікацію програми «GreenKey», що $є$ проектом Міжнародної організації 3 екологічної освіти, налічується 2900 од., у 57 країнах, що є членами програми, станом на 2018 p.[7]. 
Крім цього, Україна намагається відповідати міжнародним стандартам не лишеу готельному господарстві. У 2018 р. 13 пляжів України отримали нагороду «BlueFlag», міжнародний сертифрікат якості рекреаційних пляжів на основі відповідності 32 критеріям тестувань чистоти води прилеглої акваторії та піску, екологопросвітницької діяльності, екологічного менеджменту та безпеки. Тож, наступні пляжі мають бездоганні в екологічному відношенні водні та рекреаційні ресурси.

Готелі, що пройшли екологічну сертифікацію «GreenKey» у 2018 р.

\begin{tabular}{|l|c|l|}
\hline Місце розташування & $\begin{array}{c}\text { Кількість еко- } \\
\text { готелів }\end{array}$ & Назва еко-готелів \\
\hline Київська обл. & 2 & Eкодім «Maison Blanche» (Березівка) \\
\cline { 2 - 3 } & & Eкодім «Maison Blanche» (Mytnitsa) \\
\hline \multirow{2}{*}{ м. Київ } & 5 & RadissonBluHotel,KyivPodyl \\
\cline { 3 - 3 } & & Ekoдiм «MaisonBlancheB\&B» \\
\cline { 3 - 3 } & & Park Inn by Radisson, Kyiv Troyitska \\
\cline { 3 - 3 } & & RadissonBluHotelKyiv \\
\cline { 3 - 3 } & & InterContinentalHotel \\
\hline Івано-Франківська обл. & 1 & Radisson Blu Resort Bukovel \\
\hline
\end{tabular}

Розроблено авторами за матеріалами: [7]

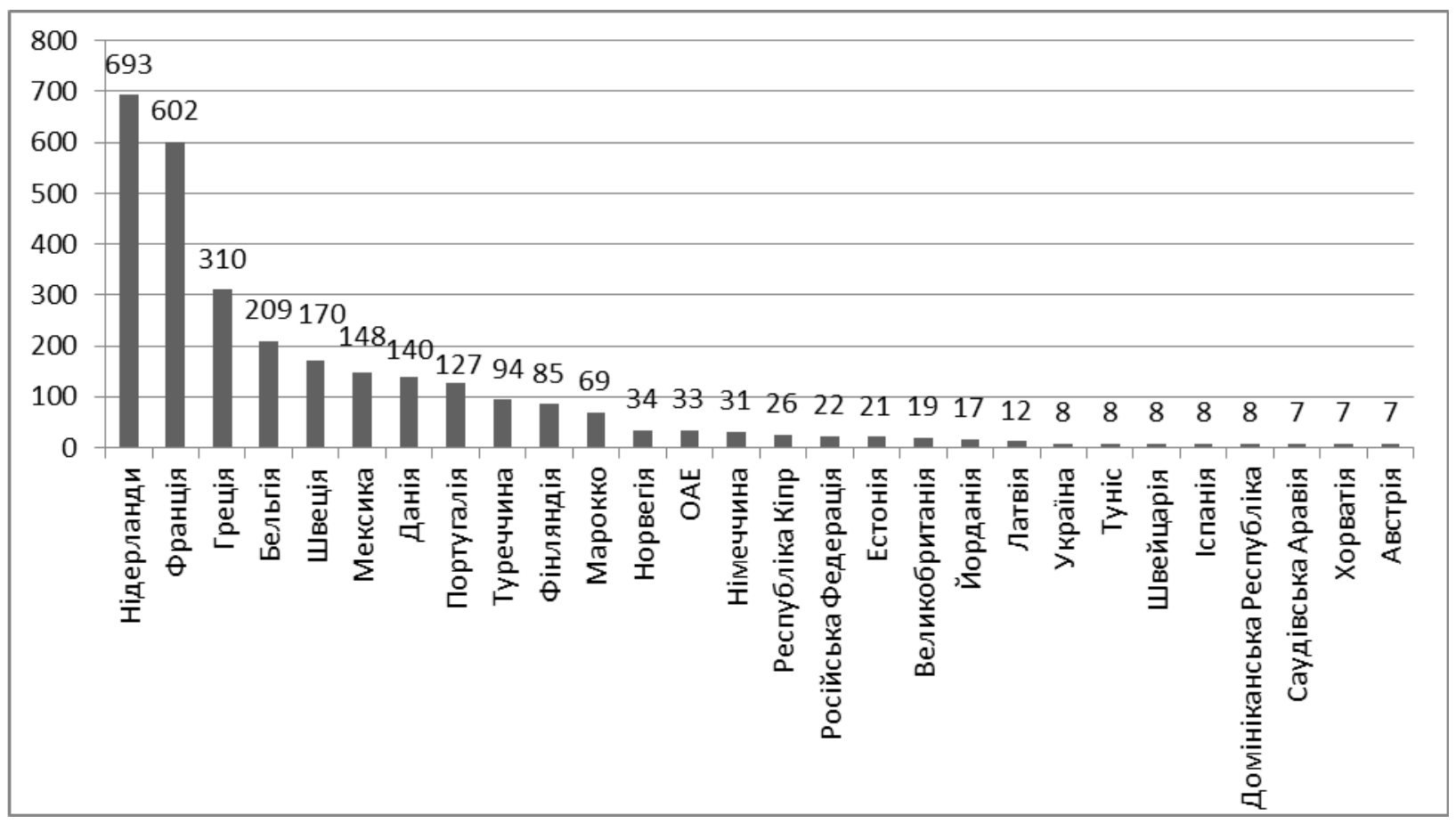

Рис. 3. Кількість готелів, сертифікованих «Зеленим ключем», 2018 р.

Розроблено авторами за матеріалами: [7]

«Блакитним прапором» відзначаються пляжі країн Європи, Південної Африки, Нової Зеландії, Канади та Карибського басейну на підставі рішення незалежного міжнародного журі, Європейською комісією з охорони навколишнього середовища. Україна посідає 26 місце серед 45 країн за кількістю пляжів 3 «Блакитним прапором», загальна кількість сертифікованих пляжів 4554 од. [6].

Розвиток екологічного туризму в Україні один із головних стратегічних напрямків, згідно 206
Стратегії розвитку туризму та курортів на період до 2026 року.

На сьогодні, екологічний туризм не користується значною популярністю серед внутрішніх туристів. Тому, більша кількість туристичних фрірм та туроператорів не організовують екологічні тури, а лише проводять екскурсії до природно-заповідного фонду країни, але назвати їх екологічними не завжди можна, адже не всі додержуються принципів екологічного туризму, та відносяться до пізнавальних турів. 
Незважаючи на це, є суб'єкти туристичної діяльності, що частково чи повністю спеціалізуються саме на екотуризмі, з них слід виокремити наступні: «ТерраІнкогніта», «Українська Асоціація активного та екологічного туризму», «Аобре поїхали», «Вилково-ПеліканТур», "ActiveUkraine», "Унікальна Україна».

Екологічний туризм в Україні організовують переважно в межах природно-заповідних територій та біля річок, тож розвивають наступні форми екологічного туризму:

- екскурсії екологічними стежками;

- піший спортивно-оздоровчий екотуризм;
- $\quad$ подорожі на велосипедах;

- $\quad$ пізнавальні подорожі;

- водний екотуризм (сплав на байдарках, рафтинг, прогулянки на човнах та ін.);

- $\quad$ спостереження за птахами (birdwatching);

-

- $\quad$ спостереження за тваринами

- краєзнавчі, зоологічні, археологічні подорожі;

- $\quad$ наукові тури;

- $\quad$ гірські подорожі.

Пляжі України, що отримали нагороду «BlueFlag» у 2018 році

Таблиця 2

\begin{tabular}{|c|c|c|}
\hline Місце розташування & Кількість & Назва пляжів \\
\hline \multirow[t]{5}{*}{ Одеська обл. } & \multirow[t]{5}{*}{5} & $\begin{array}{l}\text { Пляж «Фонтанка 2» } \\
\text { або «Zanzibar - BlackSeaRivieraBeach» }\end{array}$ \\
\hline & & Пляж «Ланжерон» ресторану «Причал №1»; \\
\hline & & Пляж «SunDali - Sun Yard Beach» \\
\hline & & Пляж «Caleton» \\
\hline & & Пляж «Чорноморська Рів'єра» \\
\hline м. Маріуполь & 1 & Пляж «Піщаний» \\
\hline \multirow[t]{7}{*}{ м. Київ } & \multirow[t]{7}{*}{7} & Пляж «Золотий» \\
\hline & & Пляж «Дитячий» \\
\hline & & Пляж «Пуща-Водиця» \\
\hline & & Пляж «Венеція» \\
\hline & & Пляж «Галера» \\
\hline & & Пляж «Веселка» \\
\hline & & Пляж «Omelca» \\
\hline
\end{tabular}

Розроблено авторами за матеріалами: [6]

Впровадження екологічно безпечних турів на туристичному ринку добре сприяє збереженню природного середовища, що тим самим підтримуєтуристичну привабливість територій [5]. Це один з особливих напрямків туризму в Україні, адже екотуризм може успішно розвиватися на туристичному ринку навіть при економічному спаді, головною умовою розвитку $є$ допомога 3 боку держави та еколого-просвітницька діяльність серед населення.

Що стосується нормативно-правового регулювання екотуризму в Україні, то на даний момент, упорядковано декілька законів щодо екотуристичної діяльності, з них Закони України: «Про туризм», «Про природно-заповідний фонА України», «Про підприємництво», «Про охорону рослинного світу», «Про тваринний світ», «Про охорону навколишнього середовища». А найбільший внесок в розвиток нормативнозаконодавчої бази роблять національні організації: Національний екологічний центр України, Українська Асоціація активного та екологічного туризму, Всеукраїнська екологічна ліга; та міжнародні: Міжнародний союз з охорони природи, Міжнародна екологічна організація,
Всесвітній фонд дикої природи, Всесвітня туристична організація [1, с. 27].

На сьогодні, в Україні центральним органом виконавчої влади щодо питань екотуризму $\epsilon$ Міністерство екології та природних ресурсів України. Саме цей орган виконавчої влади забезпечує нормативно-правове регулювання:

- охорони та використання природнозаповідного фонду;

- раціонального використання, відтворення і збереження об'єктів рослинного та тваринного світу, ландшафтного та біорізноманіття;

- формування та використання екологічної мережі;

- відтворення та охорони водних об'єктів та інших природних ресурсів.

Мінприроди керує необхідними положеннями щодо екологічної діяльності та створює умови для організації екологічного туризму.

У 2015 році відбувся саміт ООН, присвячений сталому розвитку, де були затверджені нові орієнтири та оголошені 17 глобальних цілей сталого розвитку до яких приєдналась і Україна [10]. 

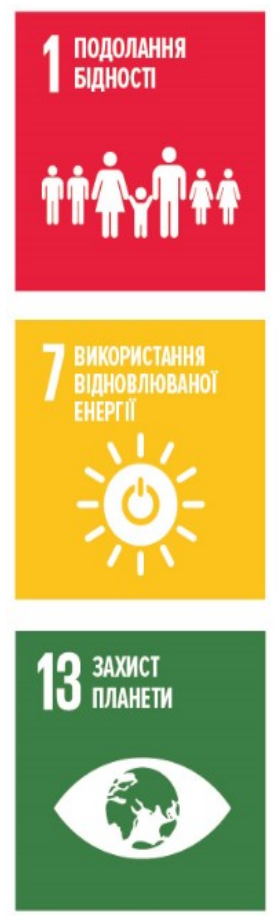
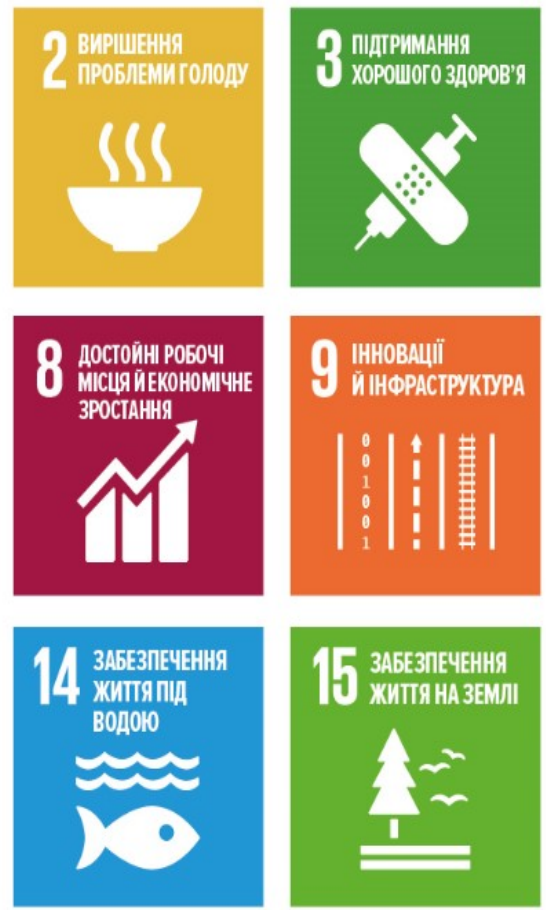
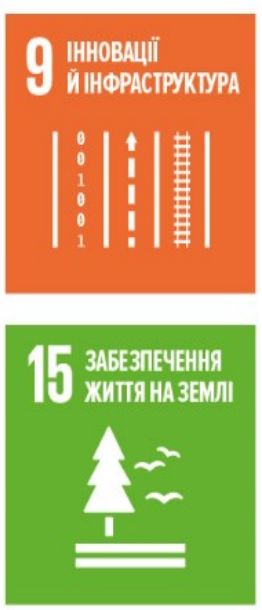
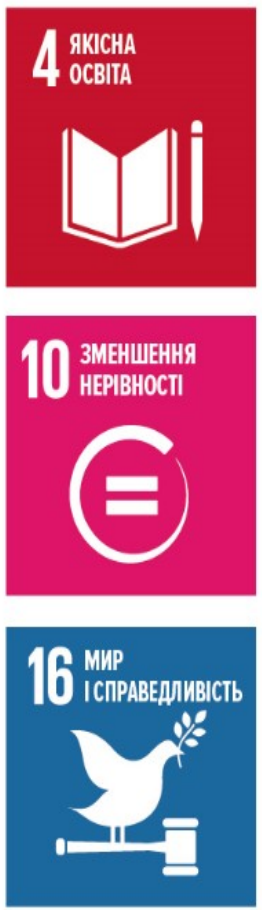
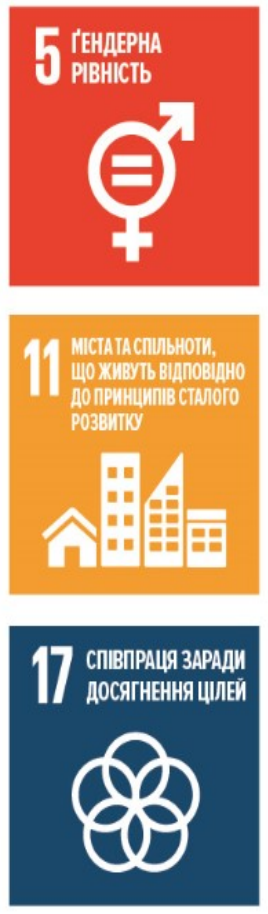
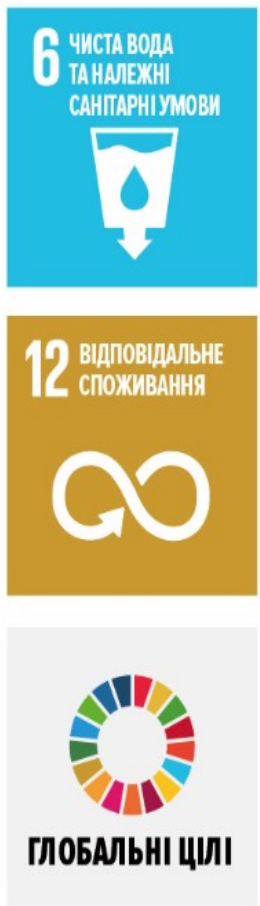

Рис. 4. Глобальні цілі сталого розвитку у світі, схвалені ООН у 2015 р. Ажерело: [10]

17 глобальних цілей є закликом до захисту планети, забезпечення миру та процвітанняі подолання бідності. Отже, Міністерством екології спільно з Європейським Союзом, в Україні була розроблена Стратегія державної екологічної політики України до 2030 року на основі 17 глобальних цілей сталого розвитку, завдяки якій країна повинна забезпечити здійснення стратегії розвитку сталого туризму, включно екологічного туризму, що сприяє створенню додаткових робочих місць, виробництву місцевих товарів та продукції, розвитку місцевої культури.Також, забезпечити населення необхідною інформацією про сталий розвиток та спосіб життя в гармонії 3 природою, сприяти розширенню та захисту лісів та природно-заповідного фонду, забезпечити збереження гірських екосистем та стале використання прибережних та морських екосистем, створити нові екологічні мережі. Все це свідчить про перспективність розвитку екологічного туризму [11].

3 кожним роком, держава впроваджує нові методи боротьби із забрудненнями навколишнього середовища. Цікавим рішенням боротьби із забрудненнями стало створення сервісу Ecomapa.gov.ua у 2016 році, інтерактивної електронної мапи зі сміттезвалищами по всім регіонам України. Кожний бажаючий може надіслати звернення про виявлене сміттєзвалище та указати його місцезнаходження, прибиранням якого в подальшому буде займатись місцева влада, а користувач сервісу, що надіслав повідомлення, може контролювати виконання робіт дистанційно.

За два роки роботи сервісу, було визначено 5 тисяч сміттєзвалищ по різним регіонам країни i половину з них було прибрано місцевою владою регіонів. Таким чином, найбільша кількість повідомлень щодо проблемних місць надійшло 3 Київської (1665 од.), Харківської (389 од.) та Аніпропетровської (354 од.) областей. Більша кількість смітників було ліквідовано в Миколаївській, Черкаській, Аніпропетровській, Харківській, Київській областях[10].

На даний момент, державна політика направлена на екологізацію виробництва та впровадження екотехнологій на екологічно небезпечних підприємствах, яких в деяких областях країни, велика кількість, що заважає не тільки розвитку екологічного туризму, а й небезпечні Аля оточуючого середовища та населення. Екологічно небезпечні підприємства спричиняють забруднення, що роблять регіони не привабливими Аля туристів.

Аналізуючи дані дії з боку держави, можна зробити висновок, що тема сталого розвитку країни дійсно важлива в усіх сфрерах діяльності, тож розвиток екологічного туризму як допомога сталого розвитку країни в цілому $є$ одним із пріоритетних напрямків. Саме тому, в останні роки в країні збільшилась кількість екологічних програм та акцій на територіях природнозаповідного фонду країни, місцева влада почала організовувати екологічні фестивалі, проекти та акції в різних регіонах країни.

На сьогодні в Україні є низка таких програм, що допомагають у покращенні навколишнього середовища: розчистити території, зробити навігаційні таблички, висадити дерева, провести реконструкцію, відновити парки тощо. 
Крім того, 3 кожним роком збільшується кількість громадських екологічних організацій на місцевому рівні. Тобто, на сьогодні, в кожній області країни є екологічні організації, що піклуються про навколишній стан середовища та впроваджують низку різних акцій та проектів, а також допомагають популяризувати екологічний туризм в регіонах. Всього громадських організацій на 2018 рік налічується 962 одинці [10].

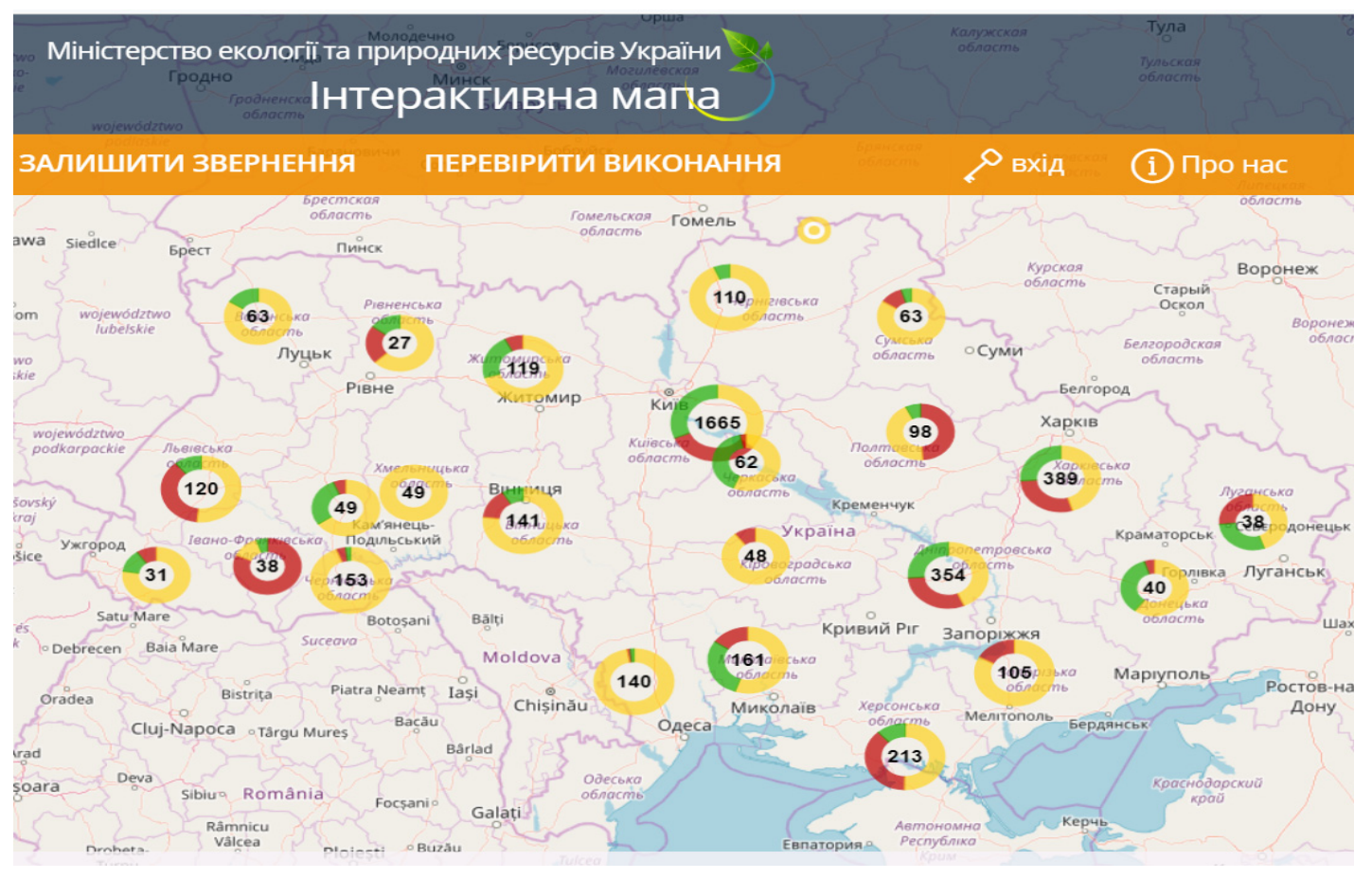

Рис. 5. Електронна мапа сміттєзвалищ по Украӥні, 2018 р.

Ажерело: [10]

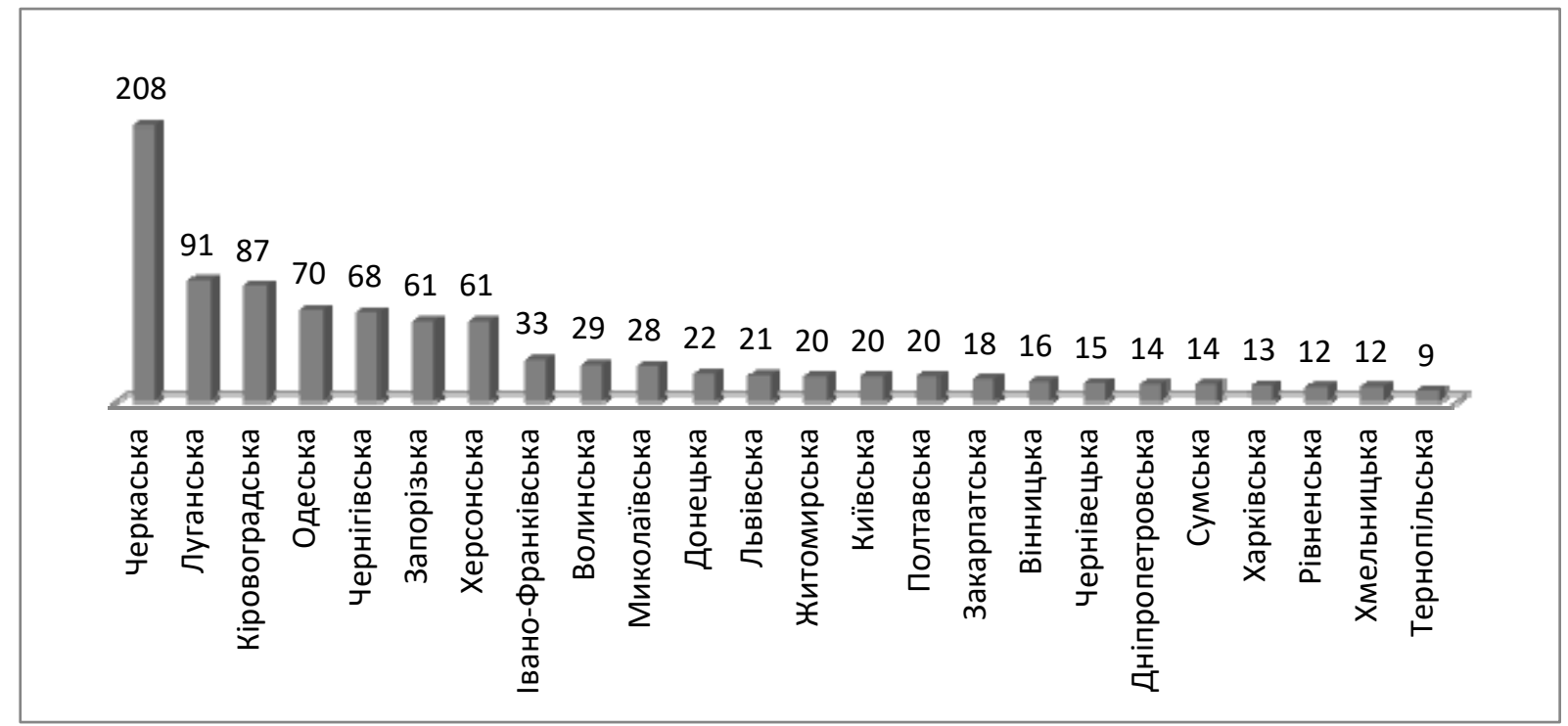

Рис. 6. Громаgські екологічні організацї (загальноgержавні та місцеві), що gіють в регіонах, станом на 01.01.2018 p., og.

Розроблено авторами за матеріалами: [10]

Тож, екологічний туризм є однією із пріоритетних цілей на державному рівні, тому $є$ перспективним напрямком на сучасному етапі становлення туристичної діяльності в Україні. Через розвиток екологічного туризму, можна досягти значних переваг в соціальній сфері країни, завдяки чому можуть змінитися погляди громадян на свій спосіб життя, збереження навколишнього середовища, тож, покращиться загальний рівень якості життя як місцевих та і сільських жителів.

В Україні є достатня кількість природнозаповідних територій, водних об'єктів, печер, Карпатські гори, різноманітні рослини та тварини. В кожній області є свої особливі рекреаційні 
ресурси, тому екотуризм може бути розвинений по всій території України, більш того, уся наявна матеріальна база для розміщення вже є (готелі, санаторії, бази відпочинку, ін.) і з кожним роком з'являються нові еко-готелі.

Аналізуючи ресурсну базу України,можна зазначити основні регіони розвитку екотуризму: Одеська, Черкаська, Полтавська, Тернопільська, Миколаївська, Закарпатська, Запорізька, Херсонська області та Полісся, а також річки: Південний Буг, Аністер, Аунай, Случ, Аесна,
Гірський Тікич, Аніпро, Чорний Черемош. В свою чергу, Харківська, Сумська, Аьвівська, Вінницька, Івано-Франківська, Хмельницька, Чернівецька області - перспективні напрямки екотуризму, але на сьогодні мало розвинені [1, с. 67].

Згідно зі статистичними даними Аержавної служби статистики України, чисельність дітей до 15 років становить 16,3 \% на 2018 рік, а осіб у віці 16-59 років - 60,8\%, тож основною цільовою аудиторією екологічного туризму на даний момент є доросле населення[9].

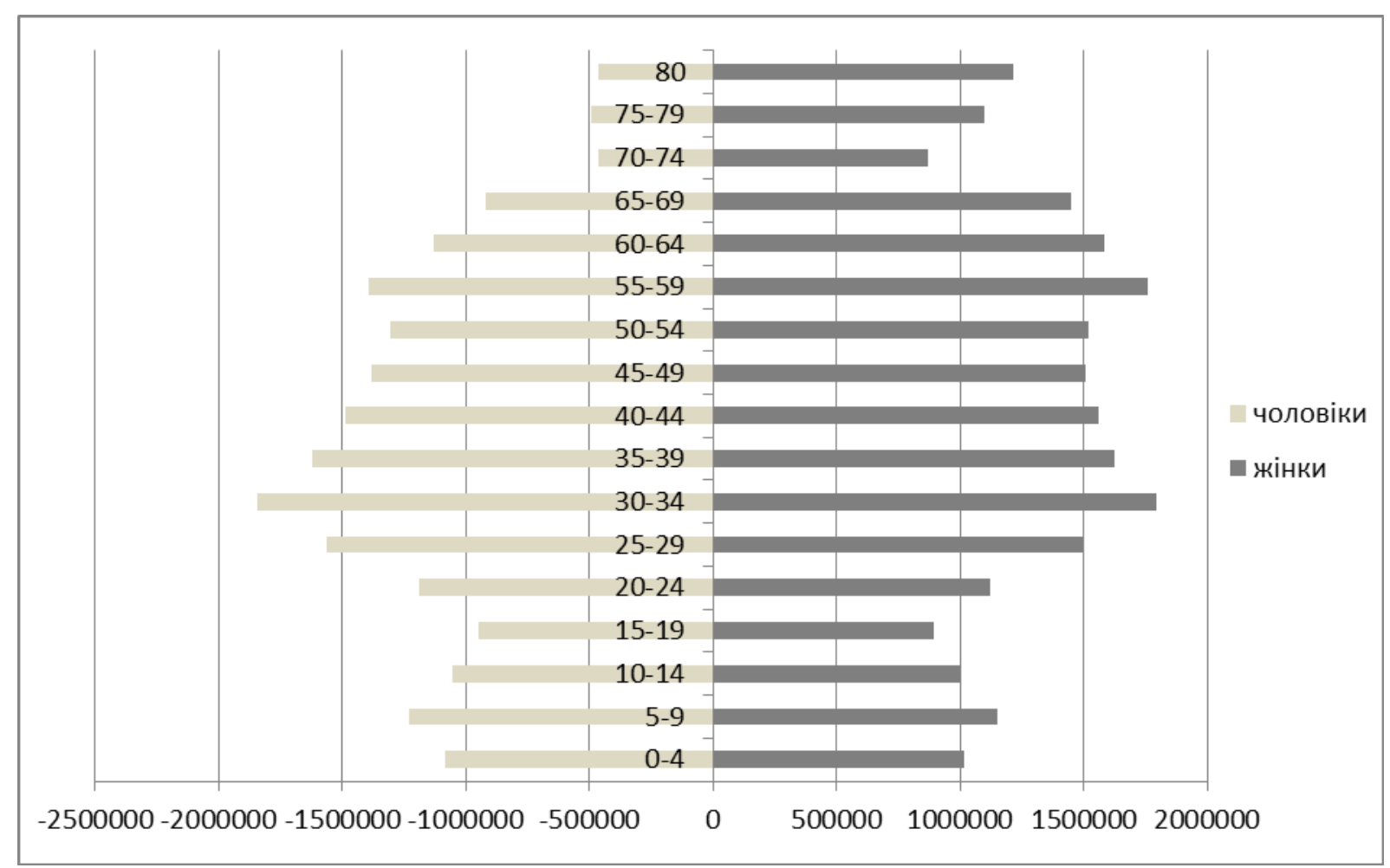

Puс. 7. Розпоgіл постійного населення Украӥни за статтю та віком, станом на 01.01.2018 p. Розроблено авторами за матеріалами: [9]

Нажаль, на даний момент, в країні відбувається процес старіння нації, тому головним завданням Аля поліпшення якості структури населення $€$ створення умов для покращення якості життя, через використання культурного та творчого потенціалу населення старшого віку.

Перспективи розвитку екологічного туризму в Україні наступні:

1. Зростання туристичного потенціалу країни.

2. Взаємодія державних та приватних структур.

3. Аоступність туристичних послуг Аля всього населення, незалежно від віку, статті, доходу та ін.

4. Підвищення екологічної свідомості населення через еколого-просвітницьку діяльність.

5. Сприяння розвитку сфрери послуг в регіонах.
6. Розробка нових туристичних маршрутів.

7. Виробництво та поширення місцевої продукції.

8. Поновлення етнічних традицій.

9. Сприяння розвитку малого та середнього бізнесу в сільській та приміській місцевості.

10. Організація зайнятості місцевого населення регіонів розвитку екотуризму.

11. Забезпечення раціонального використання природно-рекреаційних та культурно-історичних ресурсів.

Головними чинниками, що стримують розвиток екологічного туризму $€$ організаційні та економічні. Слід наголосити на неточність розуміння екотуризму населенням, погану рекламу та застарілість матеріальних ресурсів, а також популяризацію туроператорами виїзного туризму та скорочення в'їзних туристів, що не 


\begin{tabular}{|c|c|}
\hline внутрішньому & заповідного фонду країни, створенню нових \\
\hline ристичному ринку [2, с. 128]. & територій ПЗФ, підвищенню рівня екологічної \\
\hline проблемою & позитивно \\
\hline становлення & у регіонах, надає \\
\hline «greenwashing» або «зелене замилювання» коли & можливості Аля популяризації країни за кордоном, \\
\hline суб'єкти туристичної діяльності видають свої & а головне - не потребує значних інвестицій. Втім, \\
\hline послуги за екологічні, обманюючи споживачів, & Аля зацікавлення потенційної аудиторії потрібно \\
\hline недобросовісної & розробити маркетингову стратегію, що дозволить \\
\hline конкуренції [14]. & популяризувати екотуризм. ААже, на сьогодні \\
\hline Висновки. Таким чином, можна ствер & реклама екологічного туризму в країні майже \\
\hline що розвиток екологічного туризму в Україні - & відсутня. Тож, за умов постійного розвитку та \\
\hline один з найперспективніших шляхів пок & вдосконалення цього напряму, він може стати \\
\hline стану природно-заповідного & одним 3 конкурентоспроможних видів туризму \\
\hline природних територій. Організація е & \\
\hline
\end{tabular}
туризму допомагає збереженню природно-

\section{THE PROSPECTS FOR ECOLOGICAL TOURISM DEVELOPMENT IN UKRAINE}

Ivan Posokhov, Ph.D(Historical Sciences), Associate Professor, V. N. Karazin Kharkiv National University, Svobody sq., 6, Kharkov, Ukraine 61022, e-mail: ivanposokhov@karazin.ua, ORCID: https://orcid.org/0000-0001-8638-5148

Anastasia Sahaydachna, magistrate, V. N. Karazin Kharkiv National University, Svobody sq, 6, Kharkov, Ukraine 61022 , e-mail: anastasiya.vs@ukr.net, ORCID: https://orcid.org/0000-0001-5386-6025

At the present stage of tourism development in the world, the ecological tourism is one of the priority directions of sustainable development of the territories. Ecological tourism in Ukraine is at an initial stage of its expansion, but due to the existing natural and recreational resources of the country, this type of tourism has all the chances to become one of the main types of travel and create all conditions for improving the socio-economic situation of the population.

The subject of the research is the prospects for the development of ecological tourism in Ukraine on the basis of the existing resource base. The goal of the paper is to substantiate the state and the prospects of the development of ecological tourism in Ukraine. The objective: to define the essence of the concept of "ecological tourism", to analyze the current state of the development of ecological tourism in Ukraine, to consider the features of regulatory and legal regulation of ecological tourism, to determine the prospects for the development of ecological tourism.In the article general scientific methods are used such as the analysis - for the research of separate components of ecological tourism; synthesis - to combine individual facts; statistical method - for the processing of statistical information and for qualitative evaluation of data; method of induction and deduction - helps to draw conclusions based on existing facts; systematic approach - for a holistic study of the prospects of ecological tourism relative to external factors of influence.

The following results were obtained: on the basis of the analysis, the theoretical aspects of the concept "ecological tourism"are investigated, the necessary resources for the development of ecological tourism in the country are identified and the main prospects for the development of ecological tourism of Ukraine are determined. Conclusions: the prospects for the development of ecological tourism reflect the positive effect of ecotourism in Ukraine, which indicates the importance of its organization and development in the domestic tourist market of the country.

Keywords: ecological tourism, eco-hotels, environment, nature reserves, sustainable tourism development, tourism activity, Blue Flag, Green Key.

\section{ПЕРСПЕКТИВЫ РАЗВИТИЯ ЭКОЛОГИЧЕСКОГО ТУРИЗМА В УКРАИНЕ}

Посохов Иван Сергеевич, канд. истор. наук, доцент, Харьковский национальный университет имени В. Н. Каразина, пл. Свободы, 6, г. Харьков, Украина 61022, e-mail: ivanposokhov@karazin.ua, ORCID: https://orcid.org/0000-0001-8638-5148 Сагайдачная Анастасия Витальевна, магистрант, Харьковский национальный университет имени В. Н. Каразина, пл. Свободы, 6, г. Харьков, Украина 61022, e-mail: anastasiya.vs@ukr.net, ORCID: https://orcid.org/0000-0001-5386-6025

На современном этапе развития туризма в мире, одним из приоритетных направлений устойчивого развития территорий стал экологический туризм. Экологический туризм в Украине находится на начальном этапе развития, но благодаря существующим природно-рекреационным ресурсам страны, этот вид туризма имеет все шансы стать одним из основных видов путешествий и создать все условия улучшения социально-экономического положения населения.

Предметом исследования статьи перспективы развития экологического туризма в Украине на основе существующей ресурсной базы. Цель статьи состоит в обосновании состояния развития и перспектив развития экологического туризма в Украине. Задача: определить сущность понятия «экологический туризм», проанализировать современное состояние развития экологического туризма в Украине, рассмотреть особенности нормативно-правового регулирования экологического туризма, определить перспективы развития экологического туризма. В статье используются общенаучные методы исследования: анализ - для исследования отдельных составляющих экологического туризма; синтез - для объединения отдельных фрактов; статистический метод - для обработки статистической информации и для качественной оценки данных; метод индукции и дедукции - помогает сделать выводы на основе существующих фрактов; системный подход - для целостного исследования перспектив экологического туризма относительно внешних факторов воздействия.

Получены следующие результаты: на основе проведенного анализа были исследованы теоретические аспекты понятия «экологический туризм», выявлены необходимые ресурсы для развития экологического туризма в стране и определены главные перспективы развития экологического туризма Украины. Выводы: обоснованные перспективы развития экологического туризма отражают положительный эффрект от экотуристической деятельности в Украине, что свидетельствует о важности ее организации и развития на внутреннем туристическом рынке страны.

Ключевые слова: экологический туризм, эко-отели, окружающая среда, природно-заповедные территории, устойчивое развитие туризма, туристическая деятельность, BlueFlag, GreenKey. 


\section{References}

1. Vyshnevsjkyj, V. I. (2015). Ekologhichnyj turyzm: navchaljnyj posibnyk. Kyjiv: Interpres LTD. [in Ukrainian]

2. Vorobjova, O. A. (2012). Ekologhichnyj turyzm jak chynnyk stalogho rozvytku pryrodno-zapovidnykh terytorij.Kyjiv: Ekologhichni nauky. [in Ukrainian]

3. Dmytruk, O. Ju. (2004). Ekologhichnyj turyzm: Suchasni koncepciji menedzhmentu i marketynghu. Kyjiv: Aljterpres. [in Ukrainian]

4. $\quad$ Sorokina, Gh. O. (2013). Ekologhichnyj turyzm: navchaljnyj posibnyk. Lughansjk: Vyd-vo DZ «LNU im. Tarasa Shevchenko». [in Ukrainian]

5. Bochkareva, T. V. (2010). Ekoturizm: analiz sushchestvuyushchego mezhdunarodnogo opyta. Vzyato z http://tourlib.net/statti_tourism/bochkareva.htm. [in Russian]

6. Mizhnarodna proghrama «Blue Flag». (2018). Mizhnarodna proghrama «Blue Flag». Vzjato z http://www.blueflag.global. [in Ukrainian]

7. Mizhnarodna proghrama «Green Key». (2018). Mizhnarodna proghrama «Green Key». Vzjato z http://www.greenkey.global. [in Ukrainian]

8. Derzhavne aghentstvo lisovykh resursiv. (2018). Derzhavne aghentstvo lisovykh resursiv. Vzjato z http://dklg.kmu.gov.ua. [in Ukrainian]

9. Derzhavna sluzhba statystyky Ukrajiny. (2018). Derzhavna sluzhba statystyky Ukrajiny. Vzjato z http://www.ukrstat.gov.ua. [in Ukrainian]

10. Ministerstvo ekologhiji ta pryrodnykh resursiv Ukrajiny. (2018). Ministerstvo ekologhiji ta pryrodnykh resursiv Ukrajiny. Vzjato z http://www.menr.gov.ua.

11. Orghanizacija Ob'jednanykh Nacij V Ukrajini. (2018). OON $\quad v \quad$ Ukrajini. Vzjato z http://www.un.org.ua/ua/oon-v-ukraini. [in Ukrainian]

12. Pryrodno-zapovidnyj fond Ukrajiny. (2018). Pryrodno-zapovidnyj fond Ukrajiny. Vzjato z http://pzf.menr.gov.ua. [in Ukrainian]

13. Chervona knygha Ukrajiny. (2018). Chervona knygha Ukrajiny. Vzjato z https://redbook-ua.org. [in Ukrainian]

14. Centr ekologhichnoji sertyfikaciji ta markuvannja. (2018). Centr ekologhichnoji sertyfikaciji ta markuvannja. Vzjato z http://www.ecolabel.org.ua/pro-nas/politka-i-tsili. [in Ukrainian] 